\title{
INVENTARISASI JENIS DAN STRUKTUR EKOLOGI ZOOPLANKTON DI SUNGAI MUSI BAGIAN HILIR, SUMATERA SELATAN
}

\author{
Eko Prianto'), Husnah1), dan Siti Nurul Aida1) \\ 1) Peneliti pada Balai Riset Perikanan Perairan Umum, Mariana-Palembang \\ Teregristrasi I tanggal: 5 Mei 2008; Diterima setelah perbaikan tanggal: 15 Mei 2008; Disetujui terbit tanggal: 18 Juni 2008
}

\begin{abstract}
ABSTRAK
Penelitian yang bertujuan untuk mengetahui struktur komunitas zooplankton di Sungai Musi bagian hilir telah dilakukan pada bulan Mei, September, dan Januari 2007. Penelitian dilaksanakan dengan menggunakan metode survei pada 9 lokasi. Pemilihan lokasi pengambilan contoh dengan menggunakan purposive sampling didasarkan pada mikrohabitat. Contoh zooplankton diambil dengan menggunakan ember $10 \mathrm{I}$ dan total volume yang disaring dengan plankton net $150 \mathrm{I}$. Parameter yang diukur meliputi kelimpahan, komposisi jenis, keragaman, keseragaman, dan indeks dominasi zooplankton. Hasil analisis jumlah spesies zooplankton yang tertinggi dijumpai pada bulan September dan terendah pada bulan Mei. Indeks keragaman dan kelimpahan zooplankton pada Mei 2006 dan Januari 2007 berkisar antara 0 sampai dengan 2,2 dan 0,8 sampai dengan $21 \times 10^{3}$ ind. $\mathrm{m}^{-3}$. Indeks keseragaman bervariasi. Nilai yang tertinggi diperoleh pada bulan Januari $(0,8$ sampai dengan 1$)$, sedangkan bulan Mei dan September 2006. Pada September dan Mei lebih bervariasi dengan kisaran nilai masing-masing 0,6 sampai dengan 1 dan 0,6 sampai dengan 0,9. Selanjutnya untuk dominasi jenis, terdapat 2 stasiun yaitu Sebokor (bulan Mei) dan Selat Cemara (bulan September), yang didominasi 1 jenis zooplankton.
\end{abstract}

KATAKUNCl: $\quad$ zooplankton, struktur komunitas, Sungai Musi bagian hilir

ABSTRACT: Species inventoris and ecology structure of zooplankton in the down stream of Musi River, South of Sumatera. By: Eko Prianto, Husnah, and Siti Nurul Aida

\begin{abstract}
Research with aiming to know the community structure of zooplankton at the down stream of Musi Rivers was conducted in May and September 2006, and January 2007. The work was done with field survey method at nine sampling sites, that were set up by using purposive sampling method based on the difference an microhabitat. Samples for zooplankton were collected by using 10 I bucket to sample a total of 150 I of water, and the total volume of wals filtered by using plankton net. Parameters measured include the abundance, spesies composition, diversity, similarity, and dominance index of zooplankton. Results show that the highest number of zooplankton species was found in September while the lowest one was recorded in May. The diversity index and abundance zooplankton in May 2006 and January 2007 were between 0 until 2.2, and 0.8 until $21 \times 10^{3}$ ind. $\mathrm{m}^{-3}$, respectively. The similarity index varied. The highest value was recorded in january (0.8 until 1) while in may and september 2006 were 0.6 until 1 and 0.6 until 0.9, respectively. Zooplankton was dominanted sebokor and cemara sampling sites.
\end{abstract}

\section{KEYWORDS: $\quad$ zooplankton, community structure, down stream of Musi Rivers}

\section{PENDAHULUAN}

Zooplankton merupakan jasad renik atau organisme air yang memiliki peranan yang besar di dalam rantai makanan. Dalam rantai makanan zooplankton berperan sebagai konsumer ke-1 yang memakan fitoplankton, selanjutnya zooplankton ini dimakan oleh organisme lain yang lebih tinggi tingkatannya seperti udang dan ikan (Soedarsono et al., 2002). Berbeda dengan fitoplankton, zooplankton memiliki alat gerak yang sangat kecil sehingga pergerakkannya sangat halus dan terbatas. Pergerakkan zooplankton dalam perairan lebih banyak dipengaruhi oleh arus. Jenis dan kelimpahan zooplankton dapat berubah-ubah sesuai dengan kondisi lingkungan perairan. Jenis yang dapat beradaptasi dengan baik dengan lingkungan akan mendominasi wilayah tersebut. Dalam rantai makanan zooplankton memiliki peran penting yaitu sebagai konsumen I, sehingga dalam kajian ekologi perairan keberadaan zooplankton tidak dapat diabaikan.

Sungai Musi bagian hilir memiliki fluktuasi pasang surut yang cukup besar ( 1 sampai dengan $2 \mathrm{~m}$ ), pada musim kemarau diperkirakan masa air laut dapat menjangkau sampai dengan 10-an km ke arah hulu. Menurut Dahuri et al. (2001) wilayah hilir sungai selain dapat berfungsi sebagai jalur transportasi juga berfungsi sebagai penampung limbah. Dampak yang ditimbulkan dari aktivitas industri dan rumah tangga di sepanjang sungai dapat dilakukan dengan mengukur parameter fisika, kimia, dan biologi perairan 
tersebut. Parameter biologi tersebut dapat dijadikan sebagai indikator pencemaran dengan cara mengetahui keragaman dan struktur ekologi zooplankton di perairan.

Kualitas perairan sangat berpengaruh terhadap kelangsungan hidup suatu organisme dalam perairan. Keberadaan zooplankton di suatu perairan dapat dipengaruhi oleh faktor-faktor fisika kimia perairan. Sehingga untuk tumbuh dan berkembang dengan baik zooplankton memiliki batas toleransi parameter fisika kimia perairan. Paterson (1998) mengatakan bahwa komunitas zooplankton di dalam perairan sangat sensitif terhadap perubahan lingkungan. Perubahan pada struktur ekologi (keragaman, kelimpahan, dominasi, dan keseragaman) mengindikasikan bahwa perairan tersebut telah mendapat gangguan atau terjadi perubahan-perubahan.

Penelitian ini bertujuan untuk menginventarisasi jenis dan struktur ekologi zooplankton, mendapatkan data dan informasi tentang keanekaragaman, kelimpahan, dominasi, dan keseragaman zooplankton di Sungai Musi bagian hilir sebagai bahan pengelolaan sumber daya ikan di Sungai Musi.

\section{BAHAN DAN METODE}

Penelitian dilaksanakan pada bulan Mei 2006 sampai dengan Januari 2007 di Sungai Musi bagian hilir Propinsi Sumatera Selatan. Jumlah stasiun pengambilan contoh 9 titik (Gambar 1).

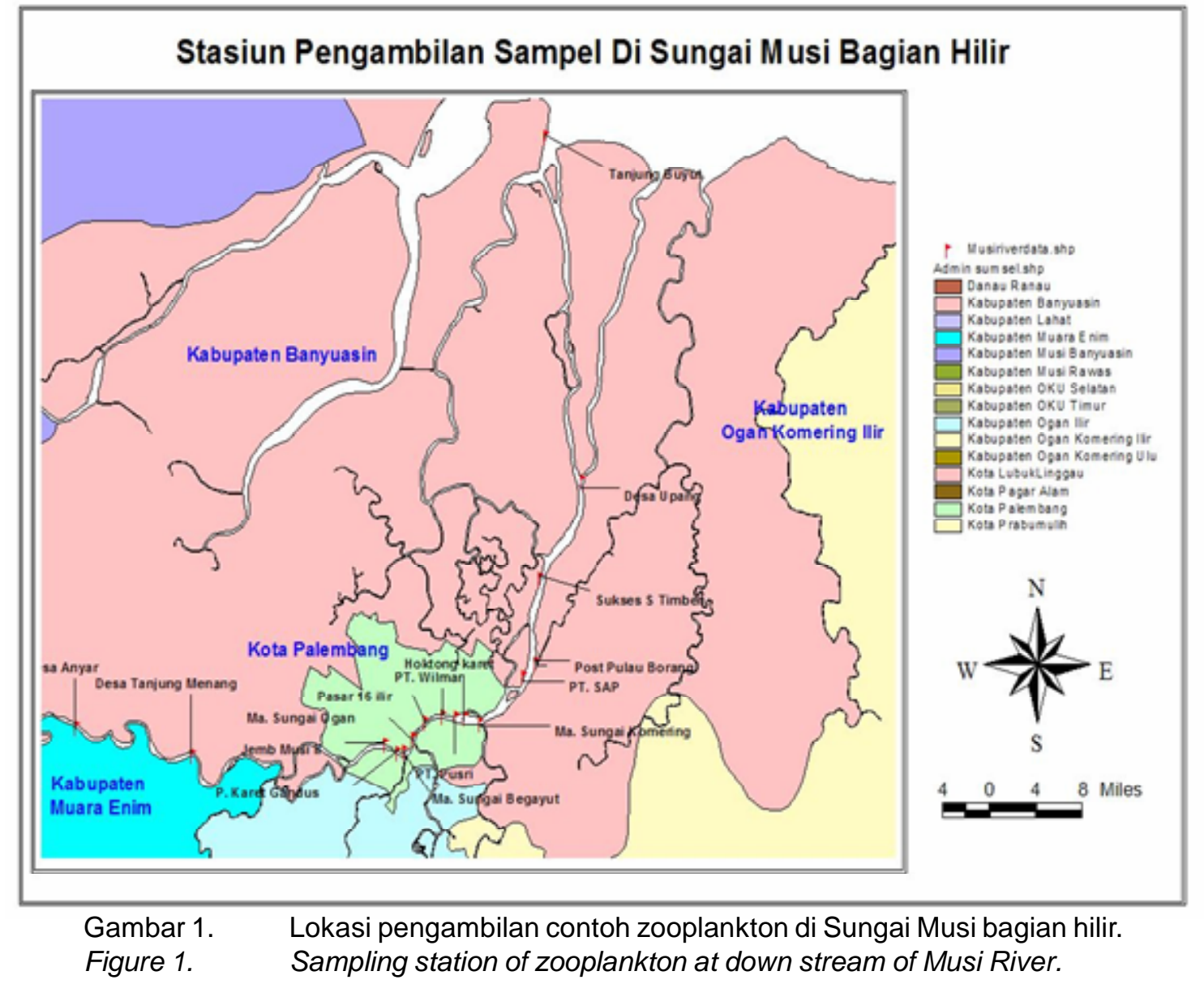

Contoh air yang mengandung zooplankton diambil dengan menggunakan ember pada bagian permukaan sungai 3 kali (tepi-tengah-tepi) dengan volume masingmasing tempat $50 \mathrm{I}$ kemudian dikompositkan (150 I). Contoh air (150 I) kemudian disaring dengan menggunakan plankton net menjadi $30 \mathrm{ml}$ dan selanjutnya diawetkan dengan menggunakan formalin $10 \%$. Contoh selanjutnya diamati di Laboratorium Hidrobiologi Balai Riset Perikanan Perairan Umum.
Contoh air diambil dengan menggunakan water sampler pada kedalaman $1 \mathrm{~m}$ dari permukaan 3 kali (tepi-tengah-tepi) kemudian dikompositkan menjadi $500 \mathrm{ml}$. Contoh air ditampung pada botol contoh plastik dan kemudian disimpan dalam cool box untuk dianalisis parameter fisika dan kimia. Parameter yang diamati yaitu suhu, kecerahan, TSS, kedalaman, kecepatan arus, Oksigen, $\mathrm{pH}$, salinitas, PO4, dan 
NO2. Contoh zooplankton diidentifikasi dengan menggunakan buku Needham \& Needham (1964); Hutabarat \& Evans (1985). Sementara analisis kualitas dilakukan menurut standart method.

Data zooplankton dianalisis dengan menggunakan rumus APHA untuk diketahui kelimpahan, sedangkan keanekaragaman jenis dianalisis dengan indeks Shannon-Wiener. Data kualitas air dibuat dalam tabel (tabulasi data) kemudian dilakukan pengelompokkan (clustering) sehingga akan diketahui parameter mana yang memiliki hubungan yang erat. Selengkapnya formula untuk analisis data zooplankton akan disajikan di bawah ini.

\section{Kelimpahan}

Perhitungan jumlah plankton dengan menggunakan rumus APHA yaitu:

$$
\mathrm{N}=\frac{100(\mathrm{PxV})}{0,25 \text { “w }}
$$

di mana:

$$
\begin{aligned}
\mathrm{P} & =\text { jumlah lapang pandang yang diamati } \\
\mathrm{V} & =\text { volume contoh plankton yang tersaring }(\mathrm{ml}) \\
" & =3,14 \\
\mathrm{~W} & =\text { volume contoh plankton yang diambil }(\mathrm{l})
\end{aligned}
$$

\section{Keanekaragaman Jenis}

$$
H^{\prime}=\sum_{i=1}^{S p i} \log _{2} \text { pi }
$$

di mana:

$$
\begin{array}{ll}
\mathrm{H} & =\text { indeks keragaman jenis } \\
\mathrm{S} & =\text { banyak jenis }(\text { taxa) } \\
\mathrm{Pi} & =\text { proporsi individu dari jenis ke-i } \\
& \text { terhadap jumlah individu semua } \\
& \text { jenis } \\
\mathrm{Ni} & =\text { banyak individu atau jenis }(\operatorname{taxa}) \\
\mathrm{N} & =\text { total individu semua jenis } \\
\text { Log perikanan } & =3,321829 \text { log } \mathrm{pi}
\end{array}
$$

\section{Keseragaman}

Perhitungan keseragaman dilakukan dengan menggunakan rumus:

$$
\mathrm{J}=\mathrm{H}^{\prime} / \mathrm{H} \text { maks }
$$

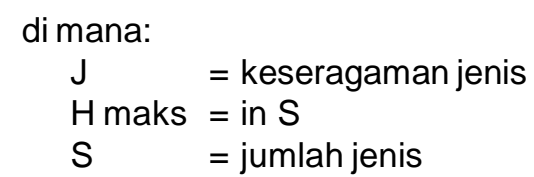

Selanjutnya Odum (1993) menegaskan indeks keseragaman merupakan angka yang tidak bersatuan yang besarnya antara 0 sampai dengan 1. Semakin kecil indeks keseragaman berarti penyebaran individu setiap jenis atau genera semakin merata dan tidak ada spesies yang mendominasi, begitu pula sebaliknya.

\section{Indeks dominansi (D)}

$$
\mathrm{D}=\mathrm{ni}^{2} / \mathrm{N}^{2} \times 100 \%
$$

\section{di mana:}

$$
\begin{aligned}
& D=\text { indeks Dominasi } \\
& \text { ni }=\text { jumlah individu jenis ke-i } \\
& N=\text { jumlah total individu }
\end{aligned}
$$

Dengan kriteria (Odum, 1993) sebagai berikut $D$ mendekati 0 tidak ada jenis yang mendominasi dan D mendekati 1 terdapat jenis yang mendominasi.

Data kualitas air dianalisis dengan menggunakan cluster analysis dengan metode hierarki, yang dimaksudkan untuk mengelompokkan parameter kualitas air ke dalam kelompok-kelompok yang homogen dari sejumlah variabel atau karakter yang digunakan (Bengen, 2000).

\section{HASIL DAN BAHASAN}

\section{Jumlah Jenis}

Hasil penelitian menunjukkan jumlah jenis zooplankton pada masing-masing musim berbedabeda, di mana jumlah jenis yang tertinggi dijumpai pada musim peralihan (35 jenis) dan terendah pada musim kemarau (13 jenis) (Gambar 2). Tinggi jumlah zooplankton pada musim peralihan diduga karena pengaruh kualitas perairan dan pasokan masa air tawar dari bagian hulu sungai lebih stabil. Sedangkan pada musim kemarau jumlah jenis lebih sedikit karena pada bagian hilir pengaruh dari air laut sangat besar sehingga berpengaruh terhadap jumlah jenis zooplankton. Menurut Dianthani (2003) jumlah spesies pada wilayah hilir (termasuk estuaria) pada umumnya jauh lebih sedikit daripada yang mendiami habitat air tawar atau di dekat air laut. $\mathrm{Hal}$ ini, antara lain karena ketidakmampuan organisme air tawar mentolerir kenaikan salinitas dan organisme air laut mentolerir penurunan salinitas.

\section{Keanekaragaman Jenis}

Hasil analisis indeks keanekaragaman zooplankton Sungai Musi bagian hilir secara 
keseluruhan berkisar antara 0 sampai dengan 2,2 (Tabel 1). Tampak bahwa dengan menggunakan indikator indeks Shanon-Wiener kondisi perairan berada pada kondisi sedang sampai dengan jelek. Rendah keanekaragaman zooplankton diduga karena arus sungai yang mengalir cukup kuat sehingga zooplankton yang berada di permukaan dengan cepat terbawa arus sungai. Di samping itu, tingkat kekeruhan yang tinggi yang berasal dari sedimen hulu sungai yang mempengaruhi perkembangan zooplankton. Walaupun zooplankton dapat bergerak, namun pergerakan sangat lemah dan terbatas sehingga pergerakan lebih banyak dipengaruhi oleh arus sungai.

\section{Jumlah Jenis Zooplankton di Sungai Musi bagian Hilir}

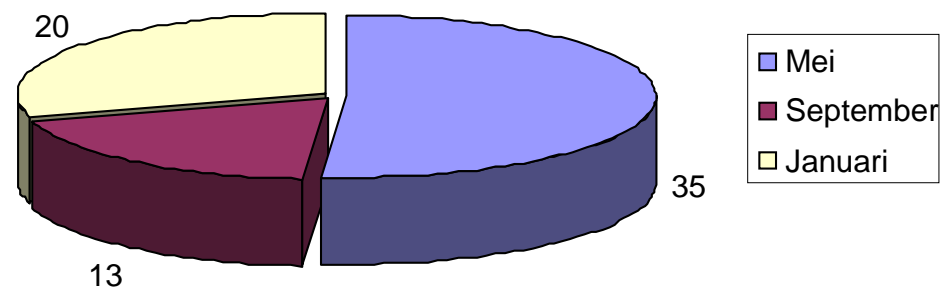

Gambar 2. Jumlah jenis zooplankton di Sungai Musi bagian hilir.

Figure 2. Number of zooplankton species at down stream of Musi River.

Tabel 1. Indeks keanekaragaman zooplankton di Sungai Musi bagian hilir

Table 1. Biodiversity index of zooplankton at down stream of Musi River

\begin{tabular}{lccc}
\hline \multirow{2}{*}{ Lokasi/Location } & Mei/May & September/September & Januari/January \\
\cline { 2 - 4 } & 2,0 & 1,1 & 1,9 \\
Desa Sejagung & 1,9 & 1,1 & 2,1 \\
Desa Pulokerto & 1,0 & 1,0 & 1,8 \\
Jembatan Ampera & 0 & 1,0 & 2,2 \\
Desa Sebokor & 0,5 & 0,9 & 1,7 \\
Pulau Burung & 2,0 & 0,5 & 1,0 \\
Desa Upang & 1,6 & 0 & 0,7 \\
Selat Cemara & 1,2 & 0,8 & 1,1 \\
Pulau Payung & 0,9 & 1,1 & 1,0 \\
Kecamatan Sungsang & & & \\
\hline
\end{tabular}

Menurut Wilh \& Dorris (1966) dalam Siagian et al. (1996) bahwa jika nilai H'>3 berarti sebaran individu tinggi atau keragaman tinggi berarti lingkungan tersebut belum mengalami gangguan (tekanan) atau struktur organisme yang ada berada dalam keadaan baik. Jika nilai H' antara 1 sampai dengan 3 berarti sebaran individu sedang atau keragaman sedang berarti lingkungan telah mengalami gangguan (tekanan) yang agak jelek. Sebaliknya jika $H^{\prime}<1$ berarti sebaran individu rendah atau keragaman rendah berarti lingkungan tersebut telah mengalami gangguan (tekanan) atau struktur organisme yang ada berada dalam keadaan jelek.

Dengan mengacu pada nilai indeks di atas terlihat bahwa perairan ini cenderung tidak stabil karena rendah keanekaragaman. Menurut Clark (1974); Krebs (1972); Arsil (1999) dalam Dianthani (2003) tinggi keanekaragaman menunjukkan suatu ekosistem yang seimbang dan memberikan peranan yang besar untuk menjaga keseimbangan terhadap kejadian yang merusak ekosistem dan spesies yang dominan dalam suatu komunitas memperlihatkan kekuatan spesies itu dibandingkan spesies lain. Ekosistem yang tidak seimbang akan mempengaruhi pakan alami sehingga jika pakan alami tidak tersedia, maka kelangsungan hidup larva organisme akan terancam. Sedangkan menurut Wetzel (2001) dalam Sulastri (2004) bahwa keragaman zooplankton di perairan tropis pada umumnya lebih rendah dibandingkan dengan daerah beriklim sedang.

Nybakken (1992) mengatakan perairan muara memiliki ciri berfluktuasi salinitas, yang akan tampak pada saat tertentu, bervariasi bergantung pada musim, topografi muara, pasang surut, dan jumlah air tawar. Ciri lain, substrat berlumpur, yang sering kali sangat lunak, berasal dari sedimen yang dibawa ke dalam muara oleh air laut maupun air tawar. Juga suhu lebih bervariasi daripada di perairan di dekat karena volume air lebih kecil, sedangkan luas permukaan lebih besar, dengan demikian pada kondisi atmosfer yang ada, 
air wilayah hilir ini lebih cepat dingin dan lebih cepat panas. Kekeruhan juga menjadi ciri perairan ini, di mana kekeruhan tertinggi terjadi saat aliran sungai maksimum. Kondisi perairan muara mempengaruhi jumlah spesies zooplankton yang mendiami sistem muara.

\section{Kelimpahan}

Kelimpahan zooplankton berkisar antara 0,8 sampai dengan $21 \times 10^{3}$ ind. $\mathrm{m}^{-3}$, dengan jumlah yang tertinggi ditemukan di stasiun Desa Sejagung pada bulan September dan terendah di stasiun Selat Cemara pada bulan Januari (Tabel 2). Namun, secara keseluruhan kelimpahan zooplankton masing-masing stasiun berfluktuasi setiap musim. Sebagai contoh pada stasiun Sejagung, pada bulan September $\left(21 \times 10^{3}\right.$ ind. $\left.\mathrm{m}^{-3}\right)$ turun menjadi $15,3 \times 10^{3}$ ind. $\mathrm{m}^{-3}$ (bulan
Mei). Begitu pula pada stasiun-stasiun yang lain. Fluktuasi kelimpahan zooplankton di bagian hilir ini diduga karena pengaruh pasang surut air sehingga keberadaan zooplankton di perairan tidak tetap. Walaupun pada bulan Januari merupakan musim hujan atau kemarau, namun kelimpahan zooplankton di bagian hilir tidak mengalami perubahan. Hal ini, disebabkan oleh fluktuasi masa air di wilayah hilir sangat di pengaruhi oleh pasang surut.

Kelimpahan zooplankton di perairan dipengaruhi oleh faktor fisika, kimia, dan biologi perairan antara lain faktor fisika (suhu, kecerahan, kedalaman, dan arus), sedangkan faktor kimia (oksigen terlarut, karbondioksida, $\mathrm{pH}$, salinitas, dan nutrien). Sedangkan faktor biologi yaitu ada organisme perairan yang memakan zooplankton (Raymond, 1963).

Tabel 2. Kelimpahan zooplankton pada masing-masing stasiun $\left(10^{3}\right.$ ind $\left.\mathrm{m}^{-3}\right)$ Table 2. Zooplankton abundance by station $\left(10^{3}\right.$ ind. $\left.\mathrm{m}^{-3}\right)$

\begin{tabular}{lccc}
\hline \multirow{2}{*}{ Lokasi/Location } & \multicolumn{3}{c}{ Bulan/Month } \\
\cline { 2 - 4 } & Mei/May & September/September & Januari/January \\
\hline Desa Sejagung & 15,3 & 21 & 7 \\
Desa Pulokerto & 5,5 & 1,3 & 17 \\
Jembatan Ampera & 2,1 & 3,4 & 18,7 \\
Desa Sebokor & 1,3 & 7,6 & 19,1 \\
Pulau Burung & 4,7 & 2,5 & 6,4 \\
Desa Upang & 9,8 & 2,1 & 1,7 \\
Selat Cemara & 4,2 & 3,0 & 0,8 \\
Pulau Payung & 5,5 & 3,8 & 7,2 \\
Kecamatan Sungsang & 8,1 & 1,3 & 2,1 \\
\hline
\end{tabular}

Samuel et al. (2003) mengatakan kelimpahan plankton (fitoplankton dan zooplankton) di Sungai Musi tergolong sedikit. Sedangkan Adjie (2007) mengatakan jenis zooplankton yang sering ditemukan adalah kelompok Cladocera (Bosmina), Copepoda (Bryocamptus, Cyclops, dan Nauplius), dan Rotifera (Bracionus, Euchlanis, Filina, Keratella, dan Polyarthra).

\section{Keseragaman}

Krebs (1978) dalam Soedarsono et al. (2002) mengatakan nilai keseragaman merupakan perbandingan antara nilai keanekaragaman suatu genera dengan keanekaragaman maksimum dalam suatu komunitas.

Berdasarkan pada analisis keseragaman zooplankton dapat dilihat pada bulan Januari nilai keseragaman tinggi (0,8 sampai dengan 1$)$, sedangkan pada bulan September dan Mei lebih bervariasi dengan kisaran nilai masing-masing 0,6 sampai dengan 1 dan 0,6 sampai dengan 0,9. Namun, secara umum keseragaman zooplankton di Sungai Musi bagian hilir cukup tinggi yang berarti penyebaran individu jenis atau genera tidak merata dan terdapat spesies yang mendominasi. Selengkapnya nilai keseragaman zooplankton di Sungai Musi bagian hilir dapat dilihat dalam Tabel 3 di bawah.

\section{Dominansi}

Pada Gambar 3 di bawah dapat dilihat terdapat 2 stasiun yaitu Sebokor (bulan Mei) dan Selat Cemara (bulan September), di mana satu jenis zooplankton yang mendominasi perairan tersebut. Sedangkan pada bulan Januari tidak terdapat dominansi zooplankton di perairan. Di stasiun sebokor dan Selat Cemara jenis yang mendominasi adalah Difflugia sp. Dilihat dari keberadaan, maka dapat ditelaah bahwa Difflugia sp.memiliki kemampuan adaptasi yang cukup baik di wilayah hilir Sungai Musi. Ada dominasi ini diduga karena kemampuan adaptasi zooplankton yang sangat baik terhadap lingkungan (faktor fisika, kimia, dan biologi) yang ekstrim. 
Tabel 3. Keseragaman zooplankton pada masing-masing stasiun di Sungai Musi bagian hilir Table 3. S Similarity zooplankton by station of down stream of Musi River

\begin{tabular}{lccc}
\hline \multirow{2}{*}{ Lokasi/Location } & \multicolumn{3}{c}{ Bulan/Month } \\
\cline { 2 - 4 } & Mei/May & September/September & Januari/January \\
\hline Desa Sejagung & 0,9 & 0,6 & 0,9 \\
Desa Pulokerto & 0,9 & 1 & 0,9 \\
Jembatan Ampera & 0,9 & 0,9 & 0,9 \\
Desa Sebokor & - & 0,9 & 0,9 \\
Pulau Burung & 0,7 & 0,8 & 0,9 \\
Desa Upang & 0,9 & 0,7 & 0,9 \\
Selat Cemara & 0,9 & - & 1 \\
Pulau Payung & 0,7 & 0,8 & 0,8 \\
Kecamatan Sungsang & 0,6 & 1 & 0,9 \\
\hline
\end{tabular}

Jika dibandingkan antar stasiun, maka Pulokerto kondisinya lebih baik dari 8 stasiun yang lain karena memiliki nilai dominansi $<0,40$. Hal ini, berarti pada 3 musim yang berbeda kondisi perairan di Pulokerto tidak terdapat dominansi jenis zooplankton (Gambar 3). Sedangkan jika dibandingkan antar musim, maka bulan Januari (musim hujan) kondisi lebih baik karena hampir setiap stasiun tidak ada jenis zooplankton yang mendominasi, dengan demikian tidak ada jenis yang mengendalikan perairan. Hilang jenis yang dominan menurut Odum (1993) akan menimbulkan perubahan-perubahan yang penting tidak hanya dalam komunitas biotik tetapi juga dalam lingkungan fisik. Ada dominasi jenis zooplankton dapat diindikasikan perairan tersebut sudah tercemar atau kurang subur sehingga hanya jenis tertentu yang mampu beradaptasi yang dapat hidup. Dominasi jenis suatu organisme merupakan salah satu indikator yang digunakan dalam menilai kualitas suatu lingkungan.

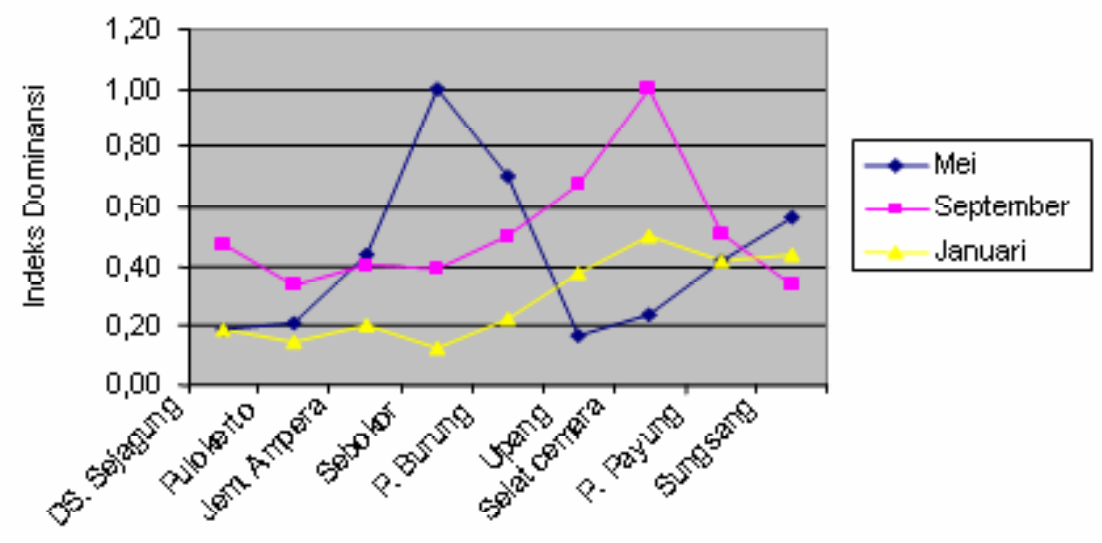

Gambar 3. Nilai indek dominasi menurut stasiun penelitian.

Figure 3. Dominance index value according to sampling station.

\section{Hubungan Kualitas Perairan dengan Kelimpahan Zooplankton}

Nutrien yang ada di dalam perairan akan dimanfaatkan oleh fitoplankton (proses fotosintesis) untuk pertumbuhan. Selanjutnya zooplankton akan memanfaatkan fitoplankton untuk kelangsungan hidup dan perkembangan. Jadi semakin baik kandungan nutrien di dalam perairan akan meningkatkan kelimpahan dan keragaman jenis zooplankton di dalam perairan. Hasil pengukuran di lapangan kualitas perairan Sungai Musi bagian hilir dapat dilihat pada Tabel 4.
Kelimpahan zooplankton di suatu perairan secara tidak langsung dipengaruhi oleh kandungan nutrien (fospat, nitrat, dan nitrit), tetapi nutrien berhubungan erat dengan pertumbuhan fitoplankton. Kandungan fosfat, nitrit, dan nitrat di perairan merupakan faktor pembatas pertumbuhan dan perkembangan fitoplankton. Menurut Adriani et al. (2003) bahwa total $P$ di perairan terdiri atas senyawa $P$ terlarut dan tidak terlarut. Senyawa $P$ terlarut berada dalam bentuk senyawa $\mathrm{P}_{-} \mathrm{PO}_{4}$. Senyawa ini merupakan sumber unsur $P$ yang dapat dimanfaatkan oleh fitoplankton atau bentos sehingga konsentrasi $\mathrm{P}-\mathrm{PO}_{4}$ di perairan merupakan indikator kesuburan perairan. 
Tabel 4. Kondisi kualitas perairan Sungai Musi bagian hilir Table 4. Water quality condition at down stream of Musi River

\begin{tabular}{|c|c|c|c|c|c|c|c|c|c|c|}
\hline $\begin{array}{l}\text { Lokasi// } \\
\text { Location }\end{array}$ & $\begin{array}{c}\text { Suhu/ } \\
\text { Temperatur }\end{array}$ & $\begin{array}{l}\text { Kecerahan/ } \\
\text { Transparency } \\
\text { (cm) }\end{array}$ & $\begin{array}{l}\text { TSS/ } \\
\text { TSS }\end{array}$ & $\begin{array}{c}\text { Kedalaman/ } \\
\text { Depth }\end{array}$ & $\begin{array}{c}\text { Arus/ } \\
\text { Current } \\
\text { (mi) }\end{array}$ & Oksigen & pH & $\begin{array}{c}\text { Salinitas/ } \\
\text { Salinity }\end{array}$ & $\mathrm{PO}_{4}$ & $\mathrm{NO}_{2}$ \\
\hline Sejagung & 29 & 26 & 0,03 & 4,3 & 2,7 & 6,1 & 7 & 0 & 0,05 & 1,66 \\
\hline $\begin{array}{l}\text { Pulokerto } \\
\text { Jembatan }\end{array}$ & 29 & 30 & 0,01 & 4,2 & 1,7 & 7,3 & 6,5 & 0 & 0,07 & 1,32 \\
\hline Ampera & 29 & 25 & 0,11 & 3 & 10,7 & 5,7 & 6,5 & 0 & 0,07 & 1,74 \\
\hline Sebokor & 27,5 & 22,5 & 0,03 & 1 & 5,7 & 4,8 & 4,5 & 0 & 0,03 & 0,98 \\
\hline Pulau Burung & 29,5 & 20 & 0,22 & 14,9 & 3,4 & 3,2 & 6,5 & 0 & 0,04 & 1,98 \\
\hline Upang & 29,5 & 32 & 0,08 & 8,1 & 2,6 & 4,4 & 7 & 0 & 0,03 & 1,72 \\
\hline Selat Cemara & 29 & 21 & 0,03 & 9 & 0,8 & 5,5 & 7 & 0 & 0,04 & 0,96 \\
\hline Pulau Payung & 29,5 & 32 & 0,05 & 10 & 2,5 & 4,9 & 7 & 0 & 0,15 & 1,22 \\
\hline Sungsang & 29,5 & 30 & 0,08 & 7,3 & 1,5 & 4,2 & 7,5 & 8 & 0,04 & 1,81 \\
\hline
\end{tabular}

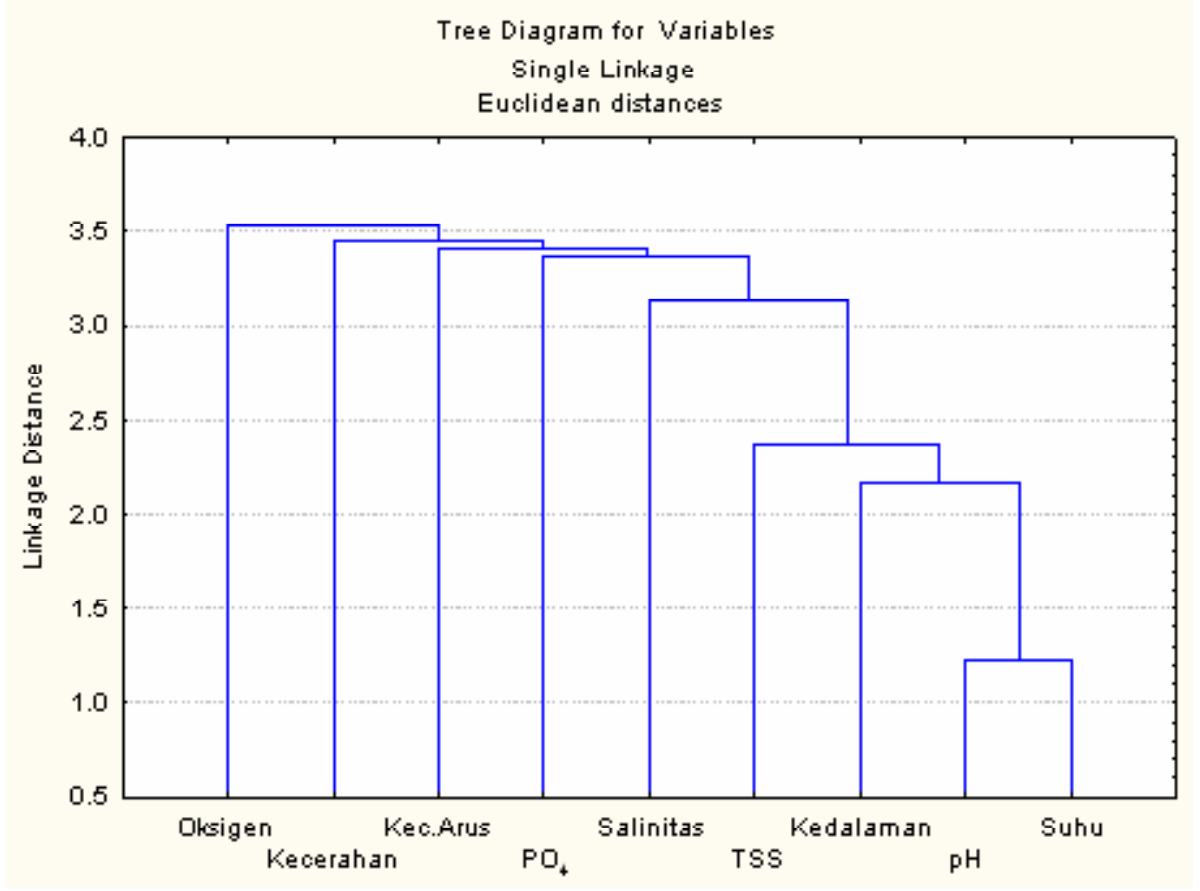

Gambar 4. Analisis pengelompokkan parameter kualitas air di Sungai Musi bagian hilir.

Figure 4. Cluster analysis of water quality at down stream of Musi River.

Suhu perairan di lokasi studi berkisar 27,5 sampai dengan $29,5^{\circ} \mathrm{C}$. Kisaran suhu ini merupakan suhu yang ideal bagi pertumbuhan zooplankton di perairan Sungai Musi. Menurut Soedarsono et al. (2002) bahwa secara umum kisaran suhu yang optimal untuk pertumbuhan plankton di daerah tropis antara 25 sampai dengan $30^{\circ} \mathrm{C}$.

Penyebaran zooplankton di sungai sangat dipengaruhi oleh arus. Di Sungai Musi bagian hilir kecepatan arus sungai berkisar antara 0,8 sampai dengan 10,7 mi (di pinggir). Sedangkan di bagian tengah sungai dapat mencapai $>20 \mathrm{mi}$. Arus yang kuat akan membawa zooplankton ke wilayah hilir sungai dan terjadi penumpukan di wilayah tersebut. Namun, dampak pasang surut terasa pengaruh di wilayah hilir, maka zooplankton akan terbawa kembali ke hulu sungai. Dengan ada faktor ini akan sulit bagi zooplankton untuk berkembang dengan baik karena akan mempersulit terhadap kemampuan zooplankton dalam memperoleh makanan.

Sungai Musi bagian hilir memiliki tingkat kecerahan yang sangat rendah. Hal ini, disebabkan oleh tinggi sedimentasi di hilir sungai karena partikel tanah di hulu dibawa arus menuju hilir. Dari data kualitas air di lapangan diperoleh nilai kecerahan berkisar antara 21 sampai dengan $32 \mathrm{~cm}$. Menurut Soedarsono et al. (2002) kecerahan air merupakan bentuk pencerminan daya tembus atau intensitas cahaya matahari yang masuk ke dalam perairan. Sifat-sifat dari bahan penyebab kekeruhan ini terutama mempengaruhi 
warna perairan, sedangkan konsentrasi menentukan kecerahan air. Kekeruhan yang disebabkan oleh partikel tanah sering merupakan faktor pembatas bagi pertumbuhan zooplankton. Berdasarkan pada hasil pengamatan di lapangan tinggi kekeruhan di Sungai Musi bagian hilir disebabkan oleh tinggi kandungan tanah dalam air.

\section{Cluster Analysis}

Parameter yang digunakan dalam penelitian ini 9 buah, di mana parameter ini memiliki pengaruh terhadap struktur komunitas zooplankton. Pada Gambar 4, jika diambil jarak keterkaitan 2,5, maka terdapat 2 kelompok yaitu $\mathrm{pH}$, suhu, kedalaman, dan TSS (kelompok 1) dan oksigen, kecerahan, kecepatan arus, $\mathrm{PO}_{4}$, dan salinitas (kelompok 2). Semakin kecil jarak keterkaitan, maka keeratan semakin besar. Menurut Paterson (1998) keragaman dan kepadatan zooplankton sangat dipengaruhi nutrient loading, acidifications, contaminant, kepadatan ikan, dan pasokan sedimen dari wilayah hulu. Hasil cluster analisis dapat dilihat pada Gambar 4 di bawah ini.

\section{KESIMPULAN}

1. Kelimpahan zooplankton di lokasi studi tergolonng rendah $\left(0,8\right.$ sampai dengan $21 \times 10^{3}$ ind. $\left.\mathrm{m}^{-3}\right)$. Hal ini, dapat disebabkan beberapa faktor fisika, kimia, dan biologi perairan tersebut.

2. Keanekaragaman zooplankton di Sungai Musi bagian hilir berada dalam kondisi rendah sampai dengan sedang. Hal ini, dapat dilihat dari nilai indeks keaneragaman ( $\left.\mathrm{H}^{\prime}\right)$ berkisar antara 0 sampai dengan 2,2. Ini mengindikasikan ditinjau dari keanekaragaman zooplankton bahwa Sungai Musi bagian hilir telah mengalami tekanan berat sampai dengan sedang.

3. Nilai indeks keseragaman di lokasi studi (3 musim) secara keseluruhan $>0,6$ dan beberapa lokasi memiliki nilai 1. Ini berarti penyebaran jenis cukup rendah dan ada dominasi jenis tertentu di perairan.

4. Dominasi jenis di 3 musim yang berbeda, hanya bulan Januari (musim hujan) tidak terdapat stasiun yang memiliki dominasi jenis tertentu (1 spesies).

5. Faktor pembatas kualitas perairan yang menyebabkan rendah zooplankton di Sungai Musi bagian hilir adalah tinggi kekeruhan dan deras arus sungai.

6. Hasil pengelompokkan kualitas perairan dengan cluster analysis diperoleh 2 kelompok yaitu $\mathrm{pH}$, suhu, kedalaman, dan TSS (kelompok 1) dan oksigen, kecerahan, kecepatan arus, $\mathrm{PO}_{4}$, dan salinitas (kelompok 2). Di mana semakin kecil nilai jarak keterkaitan, maka semakin erat hubungan antar parameter tersebut.

\section{PERSANTUNAN}

Kegiatan dari hasil riset penentuan tingkat degradasi dan validasi metode penentuan langkah degradasi lingkungan di perairan Sungai Musi, T.A. 2007, di Balai Riset Perikanan Perairan Umum, Mariana-Palembang.

\section{DAFTAR PUSTAKA}

Adjie, S. 2007. Kelimpahan dan keragaman plankton di Sungai Musi bagian hilir. Prosiding Seminar Nasional Forum Perairan Umum Indonesia IV. Pusat Riset Perikanan Tangkap. Badan Riset Kelautan dan Perikanan. Jakarta. Hal.MA 77-MA 81.

Adriani, S. N, Krismono, \& A. S. Sarnita. 2003. Penilaian ulang lima lokasi suaka perikanan di Danau Toba berdasarkan kualitas air dan parameter perikanan lainnya. Jurnal Penelitian Perikanan Indonesia Edisi Sumber Daya dan Penangkapan. Vol.9 No.3. Pusat Riset Perikanan Tangkap. Badan Riset Kelautan dan Perikanan Departemen Kelautan dan Perikanan.

American Public Health Association. 2005. Standart method for the examination of water and waste water, $21^{\text {th }}$ edition. American Publich Health Association. Washington D. C.

Bengen, D. G. 2000. Teknik pengambilan contoh dan analisis data biofisik sumber daya pesisir. Pusat Kajian Sumber Daya Pesisir dan Lautan. Fakultas Perikanan dan Ilmu Kelautan. Institut Pertanian Bogor. Sinopsis. 86 hal.

Dahuri, R., J. Rais, S. P. Ginting, \& M. J. Sitepu. 2001. Pengelolaan sumber daya wilayah pesisir dan lautan secara terpadu. PT. Pradnya Paramita. Jakarta.

Dianthani, D. 2003. Identifikasi jenis plankton di perairan Muara Badak, Kalimantan Timur. Makalah Falsafah Sains Program Pasca Sarjana. Institut Pertanian Bogor. Bogor.

Hutabarat, S. \& S. M. Evans. 1985. Kunci identifikasi zooplankton. Direktorat Jenderal Pendidikan Tinggi. Departemen Pendidikan dan Kebudayaan. 
Needham, J. G. \& P. R. Needham. 1964. A guide to the study of fresh water biology. Fifth Edition. Revised and Enlarged. Holder-day Inc. San Fransisco.

Nybakken, J. W. 1992. Biologi laut. Suatu Pendekatan Ekologis. Penerbit PT. Gramedia Pustaka Utama. Jakarta. 459 hal.

Odum, E. P. 1993. Dasar-dasar ekologi. Edisi ke-3. Gadjah Mada University Press. Yogyakarta. xv+697 hlm.

Paterson, M. 1998. Ecological monitoring and assessment network (eman) protocols for measuring biodiversity: Zooplankton in fresh waters. Department of Fisheries and Oceans Freshwater Institute 501 University Crescent Winnipeg. Manitoba.

Raymont, J. E. E. 1963. Plankton and productivity in the Ocean. Oxford. Pergamont press.

Samuel. 2006. Dinamika dan model pengelolaan perikanan perairan umum paparan banjir (rawa banjiran). Makalah Disampaikan pada Forum Perairan Umum III. Hotel Horison Palembang 2728 Nopember 2006.

Samuel, S. Adjie, \& Subagdja. 2003. Inventarisasi dan distribuís biota serta karakteristik habitat perairan Sungai Musi. Prosiding Hasil-Hasil Riset. Pusat Reset Perikanan Tangkap. Badan Riset Kelautan dan Perikanan. Jakarta. Hal.89-108.

Soedarsono, P., Subiyanto, W. Niniek, H. Sahala. 2002. Petunjuk praktikum planktonologi. Jurusan Perikanan Fakultas Perikanan Universitas Diponegoro. Semarang.

Siagian, M., Hs. Saberina, \& H. Asmika. 1996. Penuntun praktikum ekologi perairan. Fakultas Perikanan dan Ilmu Kelautan Universitas Riau. Pekanbaru. 109 hal.

Sulastri. 2004. Pengembangan sistem konservasi biota muara untuk pemanfaatan secara lestari sumber daya pesisir dan laut. Pusat Penelitian Limnologi. Lembaga Ilmu Pengetahuan Indonesia. 70 hal. 